\title{
Pediatric Malignant Liver Tumors: Results of a Single Center
}

\author{
Rejin KEBUDI ${ }^{1}$, H. Haldun EMIROGLU ${ }^{1}$, Omer GORGUN ${ }^{1}$, \\ Ferhan AKICI ${ }^{2}$, Deniz TUGCU ${ }^{2}$, Inci AYAN ${ }^{1}$ \\ ${ }^{1}$ Istanbul University, Cerrahpasa Faculty of Medicine and Oncology Institute, Division of Pediatric Hematology-Oncology \\ ${ }^{2}$ Kanuni Sultan Suleyman, Training and Research Hospital, Division of Pediatric Hematology-Oncology, Istanbul, \\ TURKEY
}

\begin{abstract}
Primary malignant tumors of the liver are rare in childhood and comprise 1-2\% of all childhood malignancies. In this retrospective study the characteristics, treatment and outcome of childhood malignant hepatic tumors diagnosed and treated in a single center between 1996 and 2010 were evaluated. The pretreatment extent of disease (PRETEXT) system was used for staging and the SIOPEL-3 or modified protocol for treatment. 20 children (13 male, 7 female), diagnosed and treated with primary malignant tumors of the liver (11 hepatocellular carcinoma [HCC], 9 hepatoblastoma [HBS]) were evaluated. In our series the cases with HCC were more than the cases with HBS. In cases with HCC, 8 had chronic hepatitis B infection. Serum alpha-fetoprotein levels were elevated in all cases with HBS and in six with HCC. According to the PRETEXT staging, 12 cases were stage (S) IV, 2 S III, 6 S II. Four had lung metastasis. Four cases with HBS, one patient with HCC are alive with no evidence of disease (19, 20, 21, 26,102 months). The high incidence of hepatocellular carcinoma in our series is thought to be due to the high incidence of hepatitis B infection in Turkey. Children with chronic hepatitis B virus infection should be followed up keeping in mind the risk of HCC. Children with hemihypertrophia and other predisposing conditions should be followed up for the risk of liver tumors so that they can be diagnosed at early stages.
\end{abstract}

Keywords: Hepatocellular carcinoma, Hepatoblastoma, Liver tumors, Pediatrics, Hepatitis B

\section{Pediatrik Malign Karaciğer Tümörleri: Tek Merkez Sonuçları}

Primer malign karaciğer tümörleri çocukluk çağında seyrek görülmekte ve tüm çocukluk çağı malignitelerinin\%1-2'sini oluşturmaktadır. Bu retrospektif çalışmada tek bir merkezde 1996 - 2010 yılları arasında tedavi gören çocukluk çağı malign karaciğer tümörü tanılı olguların klinik özellikleri, tedavi ve sonuçları değerlendirilmiştir. Tedavi öncesi hastalığın derecelendirilmesi PRETEXT sınıflandırmasına göre yapılmış ve tedavide SIOPEL-3 veya modifiye protokol kullanılmıştır. Primer malign karaciğer tümörü (11 hepatosellüler karsinom [HCC], 9 hepatoblastom [HBS]) tanısı alan ve tedavi edilen 20 çocuk hasta (13 erkek, 7 kız) değerlendirilmiştir. Serimizde HCC'li olgular HBS'lu hastalardan daha fazla idi. HCC'li hastaların 8'inde kronik hepatit B enfeksiyonu vardı. Serum alfa-fetoprotein düzeyleri HBS'li olguların tümünde ve HCC'li hastaların 6'sında yüksekti. PRETEXT sınıflandırmasına göre hastaların 12'si evre IV, 2 'si evre III, 6'sı evre II idi. 4 hastanın akciğer metastazı vardı. HBS'li 4 hasta ve HCC'li bir hasta hastalık bulgusu olmaksızın (19, 20, 21, 26, 102 aydır) yaşamaktadır. Serimizde hepatosellüler karsinom insidansının Türkiye'de kronik hepatit B enfeksiyonun yüksek insidansı nedeni ile yüksek olduğu düşünülmektedir. Kronik hepatit B enfeksiyonu olan çocuklar HCC riski göz önünde tutularak izlenmelidir. Hemihipertrofi ve diğer predispozan durumları olan çocuklar karaciğer tümörü gelişimi yönünden takip edildiklerinde erken dönemde teşhis edilebilirler.

Anahtar Kelimeler: Hepatosellüler karsinom, Hepatoblastom, Karaciğer tümörleri, Pediatri, Hepatit B 


\section{INTRODUCTION}

Primary hepatic tumors are rare in children and constitute $1.2-5 \%$ of all malignant tumors in children. Two thirds of liver tumors in children are malignant. In adults, the dominant histopathology is hepatocellular carcinoma (HCC), whereas hepatoblastoma (HBS) constitute two-thirds of malignant liver tumors in children. ${ }^{1}$ However, in developing countries due to the higher incidence of chronic hepatitis B or $\mathrm{C}$ infections in children, the incidence of hepatocellular carcinoma is higher than in developed countries. Sarcomas, germ cell tumors and rhabdoid tumors are among the other liver malignancies in children. Benign liver tumors such as vascular tumors, hamartomas, adenomas and focal nodular hyperplasia should be considered in the differential diagnosis in children. Treatment and prognosis are different according to tumor histopathology and anatomy. ${ }^{2}$

In this study, the characteristics, treatment and outcome of children with primary malignant liver tumors admitted to the Istanbul University, Oncology Institute, Division of Pediatric Hematology-Oncology between 1996 and 2010 were evaluated retrospectively.

\section{PATIENTS AND METHODS}

The demographic characteristics, initial laboratory findings, treatment and outcome of primary malignant hepatic tumors diagnosed and treated in the Istanbul University Oncology Institute, Division of Pediatric Hematology-Oncology between 1996 and 2010 were evaluated.

Thirty children were admitted for liver tumors to our center. Children with benign liver tumors evaluated in the same center such as inflammatory myofibrob- lastic tumors ( 2 cases), mesenchymal hamartomas (2 cases), focal nodular hyperplasia ( 2 cases), hemangiomas ( 3 cases) were excluded. A girl with rhabdomyosarcoma of the biliary tree, who was previously reported was also excluded. ${ }^{3}$

The remaining 20 patients with HBS or HCC were evaluated. All patients had a histopathological diagnosis obtained either by trucut biopsy or open biopsy/operation.

Among the initial laboratory data, initial laboratory findings, including complete blood count, the serum levels of alpha-fetoprotein (AFP), alanine transaminase (ALT), alkaline phosphatase (AP), aspartate transaminase (AST), gammaglutamyltransferase (GGT), and lactate dehydrogenase (LDH) were reviewed. Imaging studies including, abdominal ultrasonography (US), computed tomography (CT) and/or magnetic resonance imaging (MRI) and / or hepatic angiography, chest X-ray and $\mathrm{CT}$ were performed at diagnosis.

Tumor staging based on the pretreatment extent of the tumor (PRETEXT) system adopted by the International Childhood Liver Tumor Strategy Group (SIOPEL) was used (Table 1).

The number and location of tumors, involvement of the inferior vena cava (IVC) or hepatic veins (V), involvement of the portal veins (P), extrahepatic abdominal disease (E) and distant metastases $(\mathrm{M})$ were recorded. ${ }^{4}$

Patients were treated according to SIOPEL-3 protocol or modifications according to risk stratification. Hepatoblastoma (HB) confined to the liver and involving no more than three hepatic sectors were considered standard-risk (SR) HB, and those with HB extending into all four sectors and/or with lung me-

Table 1. Definitions of PRETEXT number

\begin{tabular}{|ll}
$\begin{array}{ll}\text { PRETEXT } \\
\text { number }\end{array}$ & Definition \\
\hline I & One section is involved and three adjoining sections are free \\
II & One or two sections are involved, but two adjoining sections are free \\
III & Two or three sections are involved, and no two adjoining sections are free \\
IV & All four sections are involved
\end{tabular}


Table 2. Tumor staging based on the PRETEXT system

\begin{tabular}{|lll|}
\hline Disease & Number of cases & Tumor staging \\
\hline Primary malignant liver tumors $(\mathrm{n}=20)$ & & \\
Hepatocellular carcinoma & 11 & II (2), IV (9), \\
Hepatoblastoma & 9 & II (4), III (1), IV (4) \\
\hline
\end{tabular}

tastases or intra-abdominal extra hepatic spread were classified as high-risk (HR) HB. SR-HB patients were treated with four courses of cisplatin (CDDP), at a dose of $80 \mathrm{mg} / \mathrm{m}^{2}$ every 14 days, delayed surgery, and then two more similar CDDP courses. If they were admitted after complete surgery, all the courses were given postoperatively. HR-HB patients were given preoperative CDDP alternating every 14 days with carboplatin (CARBO), $500 \mathrm{mg} / \mathrm{m}^{2}$, and doxorubicin (DOXO), $60 \mathrm{mg} / \mathrm{m}^{2}$. Two courses of CAR$\mathrm{BO} / \mathrm{DOXO}$ and one of CDDP were given postoperatively.

Statistical analyses were performed using the Scientific Package for the Social Sciences (version 16.0; SPSS Inc., Chicago, IL, USA). Results were expressed as median, mean values and standard deviation (SD). Quantitative variables between the two groups were compared using Mann - Whitney U test; qualitative parameters of the same groups were compared using Pearson's chi-square test with Yates' correction and Fischer's exact test. All tests of statistical significance were two-sided with a $\mathrm{p}$ value $<0.05$. The analysis of urvival rates was conducted via the Kaplan-Meier method.

\section{RESULTS}

\section{Demographic Characteristics and Initial Presen- tations}

20 children (13 boys, 7 girls; median age 9.5 years, mean age $8.2 \pm 6.0$ years, range 14 days -17 years) with primary malignant liver tumors were evaluated. Eleven were diagnosed with HCC and 9 with HBS. HCC was relatively more common than HBS in this series ( 55 vs. $45 \%$ ). There was a male preponderance in both HCC ( 7 boys, 4 girls) and HBS ( 6 boys, 3 girls) patients. The HCC patients (median age 11 years, mean age $12.2 \pm 3.2$ years, range $7.3-17$ years) were older than the HBS patients (median age 1.5 years, mean age $3.5 \pm 5.2$ years, range 14 days- 15.5 years) $(\mathrm{p}<0.001)$.

The distributions of the tumor staging of these patients are shown in Table 2. According to the PRETEXT staging, 13 cases were stage (S) IV, one III, six S II. All PRETEXT stage IV patients and a stage II patient had either extrahepatic and/or portal vein/ hepatic vein involvement. Four patients (2 HCC, 2 HBS) had lung metastasis. In nine of 20 (45\%) patients [5/11 of HCC; 4/9 of HBS] the tumor originated from the right lobe of liver.

\section{Laboratory Data}

Abnormal complete blood count and liver function tests were uncommon in pediatric liver tumors. Thrombocytosis was seen in one of $11 \mathrm{HCC}$, and in three of $9 \mathrm{HBS}$ patients. In two HBS patients the white blood cell count was also increased. The serum levels of AST were elevated in 6 of $11 \mathrm{HCC}(54.5 \%)$, and in 5 of $9(55.6 \%) \mathrm{HBS}$. The serum levels of ALT were elevated in 7 of $11 \mathrm{HCC}(63.6 \%)$, and in 3 of 9 (33.3\%) HBS. The serum levels of AP were elevated in 4 of $11(36.4 \%) \mathrm{HCC}, 1$ of $9(11.1 \%) \mathrm{HBS}$ and the serum levels of GGT were elevated in 7 of 11 $(63.6 \%) \mathrm{HCC}$, and in 7 of $9(77.8 \%)$ HBS. Only one HCC patient was icteric at diagnosis. The serum levels of LDH were elevated in 3 of $11(27.3 \%) \mathrm{HCC}$, and in 3 of $9(33.3 \%)$ HBS (Table 3$)$.

Serum alpha-fetoprotein levels were high in all nine patients with hepatoblastoma, but only in six of 11 $(54.5 \%)$ with hepatocellular carcinoma.

\section{Etiology and Associated Disease}

Eight of $11 \mathrm{HCC}$ patients were positive for hepatitis B surface antigen (HBsAg). One of these 8 cases, 
Table 3. Demographic characteristics, initial laboratory data of primary malignant liver tumors

\begin{tabular}{lll|}
\hline & HCC $\mathbf{n = 1 1}$ & HBS $\mathbf{n = 9}$ \\
\hline Age* (years) & 11 (7.3-17.0) & 1.5 (0.04-15.5) \\
Male/Female & $7 / 4$ & $6 / 3$ \\
Leukocytosis & 0 & 2 \\
Thrombocytosis & 1 & 3 \\
AST elevation (number of subject) & 6 & 5 \\
ALT elevation (number of subject) & 7 & 3 \\
AP elevation (number of subject) & 4 & 1 \\
GGT elevation (number of subject) & 7 & 7 \\
Total bilirubin elevation (number of subject) & 1 & 0 \\
LDH elevation (number of subject) & 3 & 3 \\
AFP* (ng/mL) & 10605 (3-1764680) \\
AFP elevation (number of subject) & 6 & 4063 (265-441161) \\
\hline
\end{tabular}

was also anti-HCV seropositive. All HBS patients, were seronegative for $\mathrm{HBsAg}$ and anti-HCV. One patient with HCC had tyrosinemia. There was a history of androgen treatment in a patient with Fanconi anemia who developed HCC. Two HBS patients had hemihypertrophia, actually the 14 day-old baby was diagnosed with HBS after an abdominal US was requested for a possible associated disease with hemihypertrophia.

\section{Therapy and Outcome}

Patients were treated according to SIOPEL-3 protocol or modifications according to age/risk stratification.

\section{Hepatoblastoma Patients}

Four patients were Standard risk. Two babies with HBS PRETEXT stage II and hemihypertrophy, were admitted after complete resection (lobectomy), another baby with stage II HBS underwent complete resection (lobectomy) after chemotherapy. The 14 day- old baby received 4 courses of carboplatinum (18 $\mathrm{mg} / \mathrm{kg}$ ) only every 14 days postoperatively. The other two received a total of 6 courses of cisplatinum (2.7 $\mathrm{mg} / \mathrm{kg} /$ course) only, according to the standard risk arm of SIOPEL-3 protocol. They are alive with no evidence of disease (NED) $+20,+26$, and +102 months after diagnosis.

One stage IV HBS patient with no extrahepatic/vein involvement /distant metastasis, received cisplatinum and doxorubicin (PLADO), had no objective response after 3 courses, underwent orthotopic liver transplantation from his father and received no further chemotherapy. He had lymphoproliferative disease 7 months after transplant and lives 19 months after diagnosis.

One HBS stage III patient with no extrahepatic/vein involvement/distant metastasis, who received preand postoperative chemotherapy and underwent trisegmentectomy, relapsed, had salvage chemotherapy and chemoembolization, but died of progressive disease 22 months after diagnosis. 


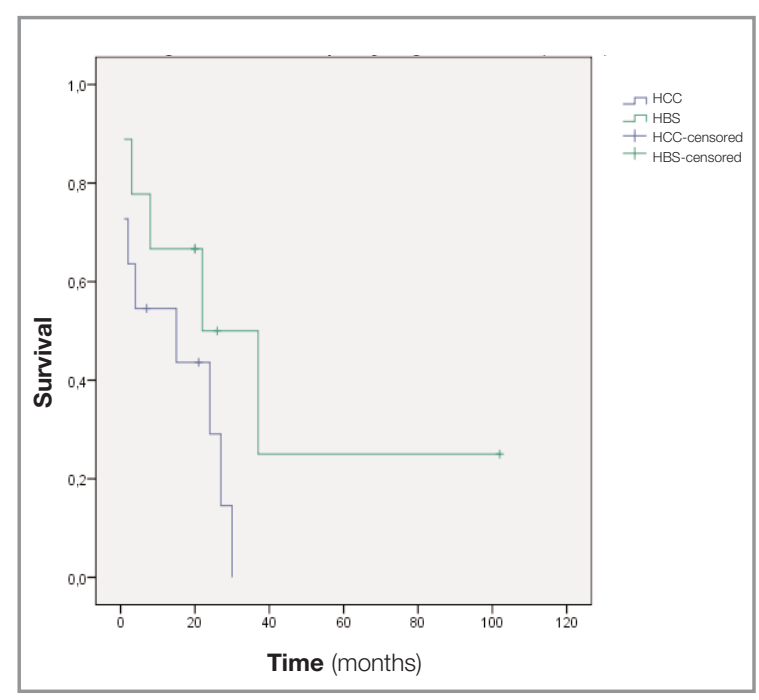

Figure 1. Survival rates of primary malignant liver tumors (HCC/HBS)

Two patients with PRETEXT IV and extrahepatic involvement/lung metastasis died with progressive disease in two months. One patient with PRETEXT IV and extrahepatic involvement, who achieved complete remission with cisplatinum/doxorubicin/carboplatinum chemotherapy and underwent trisegmentectomy, relapsed, had salvage chemotherapy and chemoembolization, but died of progressive disease 37 months after diagnosis. One with stage II but extrahepatic involvement died at 8 months with progressive disease. One year survival rate for was $77.8 \%$ (7 of 9 cases). Four out of nine patients are alive at a median of 24 months (19-22 months) after diagnosis. The 2 year cumulative survival rate was $50 \%$ (Figure 1).

\section{Hepatocellular Carcinoma Patients}

One patient with PRETEXT II fibrolamellar HCC (FL-HCC) and no extrahepatic/vein involvement /distant metastasis was admitted after a lobectomy. $\mathrm{He}$ was treated with cisplatinum/doxorubicin/carboplatinum according to SIOPEL-3 and is with NED 21 months after diagnosis. One PRETEXT IV patient with tyrosinemia received orthotopic liver transplantation and died at 15th month after the liver transplantation with complications. Two PRETEXT IV patients with lung metastasis and widespread extrahepatic metastasis had a major regression of the lung and extrahepatic metastasis after cisplatinum/doxorubicin/carboplatinum, one also had an incomplete resection of the tumor, and both progressed, had salvage chemotherapy/chemoembolization/sorafenib, but died 7 and 27 months after diagnosis respectively. One patient with PRETEXT II and extrahepatic disease was a cancer survivor who had been infected with hepatitis B during chemotherapy for non Hodgkin's lymphoma, developed chronic hepatitis and HCC; she died at 24 months with progressive disease. Seven patients with PRETEXT IV and extrahepatic metastasis but no distant metastasis all died with progressive disease 1-15 months after diagnosis, they had received cisplatinum/doxorubicin/carboplatinum/salvage chemotherapy/chemoembolization. The 2 year survival rate was 29\% (Figure 1).

\section{DISCUSSION}

Primary hepatic tumors are rare in children and constitute $1.2-5 \%$ of all malignant tumors in children. According to the Turkish Pediatric Oncology Group and Turkish Pediatric Hematology Societies Registry, the incidence of malignant liver tumors is $1.5 \%$ among all malignancies in Turkish Children. ${ }^{5}$

HBS is the most common primary liver tumor in children. Hepatoblastoma (HBS) constitute twothirds of malignant liver tumors in children ${ }^{6.7} \mathrm{HBS}$ constitute more than $90 \%$ of malignant liver tumors in children fewer than two years of age. ${ }^{8}$ The median age of children with HBS was 1.5 years in our study as in most series in the literature. The relationship between very low birth weight and increased incidence of HBS has been reported in recent years ${ }^{9}$, however none of our cases were born with very low birth weight.

HBS in children may be sometimes associated with some diseases or malformations such as hemihypertrophia..$^{10}$ In our study $2(22.2 \%)$ of 9 HBS patients had hemihypertrophia. Actually the 14 day-old baby was diagnosed with HBS after an abdominal US was requested for a possible associated disease with hemihypertrophia.

Some diseases such as several types of congenital metabolic diseases including tyrosinemia ${ }^{11}$, glycogen storage disease- ${ }^{12}$, PiZZ alpha-1 antitrypsin deficiency $^{13}$, and Alagille syndrome ${ }^{14}$ have been reported to be predisposing to HCC in children. Children with 
some liver diseases with severe cholestasis such as biliary atresia ${ }^{15}$, progressive familial intrahepatic cholestasis (PFIC) $)^{16}$ and liver mitochondrial respiratory chain disease ${ }^{17}$ are at an increased risk of developing HCC also. In our study HCC was seen in a patient with tyrosinemia, a patient with Fanconi anemia treated with androgens, most of the others had chronic hepatitis B. Fibrolamellar HCC occurs more often in older children and adolescents representing $30 \%$ of HCC cases less than 20 years of age. FLHCC is usually not associated with cirrhosis or viral hepatitis. Thirty percent of FL-HCC has metastases at the time of diagnosis..$^{10}$ Among 11 HCC patients, one $(9.1 \%)$ had FL-HCC. This patient was 17-yearold boy, had no history of hepatitis B or C, and had no metastasis and is alive with NED.

In contrast to HBS, the median age for children with HCC is $10-11.2$ years. ${ }^{18}$ In our study the median age for HCC was 11 years, supporting the data in the literature. There is a strong association between inflammation related to HBV or HCV and HCC. ${ }^{19}$ Turkey is located in an intermediate area for HBsAg endemicity. ${ }^{20}$ High seropositivity rates of hepatitis B virus in Turkish pediatric hematology-oncology patients have been reported. ${ }^{21,22}$ One of the HCC patients was infected with HBV during treatment for her primary malignancy, lymphoma. Due to high rate of Hepatitis B in Turkey, HCC is relatively more common than HBS in this series.

Although most children with HBS have an elevated serum AFP level, this marker is elevated in only 50$70 \%$ of patients with HCC. ${ }^{2}$ The serum AFP levels may be normal in the patients with FL-HCC. ${ }^{10}$ As expected, in our study high serum AFP levels at diagnosis were detected in 6 of 11 HCC patients $(54.5 \%)$ and in all patients with HBS. The serum AFP level of our patient with FL-HCC was within normal limits. Extremely high levels of AFP may occur in HCC patients with advanced disease. Liver biochemical test abnormalities including elevated serum levels of ALT, bilirubins and AP have usually been reported in adult patients with primary and metastatic liver tumors. ${ }^{1}$ In our study although not as frequent as in adults, abnormalities in liver enzymes ALT, AST and GGT were observed, especially in children with advanced stage disease. However elevated LDH, total bilirubin or AP levels were less frequent.
The course of HBV-related HCC in children is different than adults. Therefore, early diagnosis and treatment of pediatric HCC for HBV-endemic areas are known to be more important. ${ }^{1}$ Children who are HBV carriers or who have chronic hepatitis B virus infection should be followed up keeping in mind the risk of HCC. Obtaining abdominal ultrasonography and serum AFP levels every 6 months is recommended. ${ }^{23}$ Children with hemihyperthrophy and other predisposing conditions should be followed up for the risk of liver tumors so that they can be diagnosed at early stages.

One patient with HCC and tyrosinemia who had had a successful living related liver transplantation, unfortunately died due to late complications. In a large series of liver tumors reported, five patients had HCC or HBS associated with tyrosinemia. Three of these who had undergone living related liver transplantation were long term survivors. Thus, in these patients, liver transplantation may be curative for both liver tumor and tyrosinemia. ${ }^{24}$

The survival of hepatoblastoma has increased significantly in the last decades by the use of chemotherapy, surgery/transplantation. ${ }^{25-27}$ In the SIOPEL-3 high risk study, 3 year survival was reported as $69 \%$ for the whole group, and $62 \%$ for metastatic cases. In Children Oncology Group studies, similar results were reported. In our series, only 4 of the 9 HBS patients, three of whom had standard risk HBS, are alive. All others had either lung metastasis or widespread extrahepatic metastasis and could not be cured. This may explain the low survival rate in our series. In hepatocellular carcinoma the survival rate is below $30 \%$ in cooperative group studies such as SIOPEL. ${ }^{28}$ The only chance of cure in HCC is complete resection of tumor. In our series also, the survival in HCC was dismal, despite all salvage chemotherapy, chemoembolization, sorafenib in this limited series, most of our HCC patients had advanced widespread disease.

As a result, early diagnosis and treatment of childhood primary liver malignant tumors is very important. The high incidence of hepatocellular carcinoma in our series is thought to be due to the high incidence of hepatitis B infection in Turkey. The incidence of $\mathrm{HCC}$ is expected to decrease as a result of routine application of free hepatitis B vaccine to all children 
in Turkey from birth on. Children with chronic hepatitis B virus infection should be followed up for liver malignancies before the emergence of symptoms and signs for liver tumors. Even if the results of liver tests in children with HBsAg are normal, serum alpha-fetoprotein level measurement and abdominal ultrasonography are recommended to be performed at least twice a year. Children with diseases predisposing to liver malignancies such as some metabolic diseases or hemihypertrophia should also be followed up so that they can be diagnosed at early stages. Diagnosis at early stages may lead to high survival with multimodality treatment.

\section{ACKNOWLEDGEMENTS}

We would like to thank to Prof. Alaettin Celik, Prof. Tansu Salman, Prof. Cenk Buyukunal, Prof. Osman Faruk Senyuz, Prof. Munci Kalayoglu for consulting and operating the patients, Prof. Tiraje Celkan for the treatment of the lymphoproliferative disease and Asst. Prof. Hakan Camlica from the Department of Epidemiology of Cancer and Biostatistics, Oncology Institute, Istanbul University for performing the statistical analysis.

\section{REFERENCES}

1. Wang JD, Chang TK, Chen HC, et al. Pediatric liver tumors: Initial presentation, image finding and Outcome. Pediatr Int 49: 491-496, 2007.

2. Litten JB, Tomlinson GE. Liver Tumors in Children. The Oncologist 13: 812-820, 2008.

3. Kebudi R, Gorgun O, Ayan I, et al. Rhabdomyosarcoma of the biliary tree: case report and review of the literature. Pediatr Int 45: 469-471, 2003.

4. Roeuck DJ, Aronson D, Clapuyt P, et al. 2005 PRETEXT: a revised staging system for primary malignant liver tumours of childhood developed by the SIOPEL group. Pediatr Radiol 37: 123-132, 2007.

5. Kutluk T, Yesilipek MA. Turkish national pediatric cancer registry 2002-2008 (Turkish Pediatric Oncology Group and Turkish Pediatric Hematology Society). Pediatr Blood Cancer (Abstract) 53: 851, 2009.

6. Stocker JT. Hepatic tumors in children. Clin Liver Dis 5: 259-281, 2001.

7. Emre S, McKenna GJ. Liver tumors in children. Pediatr Transplant 8: 632-638, 2004.

8. Bulterys M, Goodman MT, Smith MA, Buckley JD. Hepatic Tumors. In: Ries LAG, Smith MA, Gurney JG, et al. (eds). Cancer Incidence and Survival among Children and Adolescents: United States SEER Program
1975-1995, National Cancer Institute, SEER Program. NIH Pub. No. 99-4649. Bethesda, MD, 1999: 91-97.

9. Schnater JM, Kohler SE, Lamers WH, et al. Where do we stand with hepatoblastoma? Cancer 98: 668-678, 2003.

10. Otte JB. Progress in the surgical treatment of malignant liver tumors in children. Cancer Treat Rev 36: 360-371, 2010.

11. van Spronsen FJ, Bijleveld CM, van Maldegem BT, Wijburg FA. Hepatocellular carcinoma in hereditary tyrosinemia type 1 despite 2-(2 nitro 4-3 trifluoromethylbenzoyl)- 1, 3 cyclohexanedione treatment. J Pediatr Gastroenterol Nutr 40: 90-93, 2005.

12. Franco LM, Krishnamurthy $\vee$, Bali D, et al. Hepatocellular carcinoma in glycogen storage disease type 1a: a case series. J Inherit Metab Dis 28: 153-162, 2005.

13. Hadzic N, Quaglia A, Mieli-Vergani G. Hepatocellular carcinoma in a 12 year old child with PiZZ alpha-1-antityrpsin deficiency. Hepatology 43: 194, 2006.

14. Halvorsen RA Jr, Garrity S, Kuni C, et al. Arteriohepatic dysplasia (Alagille's syndrome): unusual hepatic architecture and function. Abdom Imaging 20: 191196, 1995.

15. Brunati A, Feruzi Z, Sokal E, et al. Early occurrence of hepatocellular carcinoma in biliary atresia treated by liver transplantation. Pediatr Transplant 11: 117-119, 2007.

16. Whitington PF, Freese DK, Alonso EM, et al. Clinical and biochemical findings in progressive familial intrahepatic cholestasis. J Pediatr Gastroenterol Nutr 18: 134-141, 1994.

17. Scheers I, Bachy V, Stephenne X, Sokal EM. Risk of hepatocellular carcinoma in liver mitochondrial respiratory chain disorders. J Pediatr 146: 414-417, 2005.

18. De Ugarte DA, Atkinson JB. Liver tumors. In: Pediatric surgery. Grosfeld JL, O'Neill Jr JA, Fonkalsrud AG, Coran AG (eds). 6th edition. Mosby-Elsevier, Philadelphia, 2006: 502-505.

19. Czauderna P, MacKinlay G, Perilongo G, et al. Hepatocellular carcinoma in children: results of the first prospective study of the International Society of Pediatric Oncology Group. J Clin Oncol 20: 2798-2804, 2002.

20. World Health Organization. Introduction of hepatitis B vaccine into childhood immunization services. Geneva, World Health Organization, 2001 (unpublished document WHON\&B/01.31; available on request from Department of Vaccines and Biologicals, World Health Organization, 1211 Geneva 27, Switzerland).

21. Kebudi R, Ağaoğlu L, Badur S. The seroprevalence of HIV-1 and HBV infections in multitransfused pediatric hematology-oncology patients in Istanbul. Pediatr Hematol Oncol 9: 389-391, 1992.

22. Kebudi R, Ayan I, Yllmaz G, et al. The seroprevalence of hepatitis B, hepatitis C and human immunodeficiency virus infections in children with cancer at diagnosis and following therapy in Turkey. Med Pediatr Oncol 34: 102-105, 2000. 
23. Wen $\mathrm{WH}$, Chang MH, Hsu HY, et al. The development of hepatocellular carcinoma among prospectively followed children with chronic hepatitis B virus infection. J Pediatr 144: 397-399, 2004.

24. Büyükpamukçu $M$, Varan $A$, Haberal $M$, et al. The efficacy of liver transplantation in malignant liver tumors associated with tyrosinemia: Clinical and laboratory findings of five cases. Pediatr Transplantation 10: 517520, 2006.

25. Zsiros J, Maibach R, Shafford E, et al. Successful treatment of childhood high-risk hepatoblastoma with dose-intensive multiagent chemotherapy and surgery: final results of the SIOPEL-3HR study. J Clin Oncol 28: 2584-2590, 2010.

26. Cacciavillano WD, Brugières $L$, Childs $M$, et al. Phase II study of high-dose cyclophosphamide in relapsing and/or resistant hepatoblastoma in children: a study from the SIOPEL group. Eur J Cancer 40: 2274-2279, 2004.

27. Meyers RL, Rowland JR, Krailo M, et al. Predictive power of pretreatment prognostic factors in children with hepatoblastoma: a report from the Children's Oncology Group. Pediatr Blood Cancer 53: 1016-1022, 2009.

28. Czauderna P. Adult type vs. Childhood hepatocellular carcinoma--are they the same or different lesions? Biology, natural history, prognosis, and treatment. Med Pediatr Oncol 39: 519-523, 2002.

\section{Correspondence}

Prof. Dr. Rejin KEBUDI

İstanbul Üniversitesi Onkoloji Enstitüsü

Pediatrik Hematoloji-Onkoloji Bilim Dalı

Çapa, Istanbul / TURKEY

Tel: (+90.212) 4142434 Ext: 34240

Fax: (+90.212) 5348078

e-mail: rejinkebudi@yahoo.com 